\title{
THE SOCIAL STRUCTURE OF EUROPEAN INEQUALITY A multidimensional perspective
}

\author{
Rosário Mauritti \\ ISCTE, Lisbon University Institute, Centre for Research and Studies in Sociology (CIES), Lisbon, Portugal \\ Susana da Cruz Martins \\ ISCTE, Lisbon University Institute, Centre for Research and Studies in Sociology (CIES), Lisbon, Portugal \\ Nuno Nunes \\ ISCTE, Lisbon University Institute, Centre for Research and Studies in Sociology (CIES), Lisbon, Portugal \\ Ana Lúcia Romão \\ School of Social and Political Sciences (ISCSP-ULisboa), Centre for Research and Studies in \\ Sociology (CIES), Lisbon, Portugal \\ António Firmino da Costa \\ ISCTE, Lisbon University Institute, Centre for Research and Studies in Sociology (CIES), Lisbon, Portugal
}

\begin{abstract}
The aim of this article is to present some contributions to the understanding of social inequality in Europe today. We analyse the distributional inequalities of economic and educational resources as well as the categorical inequalities between nation states and between social classes. The source of the empirical data was the European Social Survey 2012. We were able to calculate European income deciles, build a matrix of class-country segments, and analyse the intersections of this structural matrix with the distributions of income and schooling. The results reveal high degrees of distributional inequality in Europe. They also show the structural configurations assumed in Europe by the intersection of distributive and categorical inequalities.

$\underline{\text { Keywords }}$ inequality, Europe, income, education, class.
\end{abstract}

Resumo O objetivo deste artigo é apresentar alguns contributos para a compreensão das desigualdades sociais na Europa atual. Analisam-se as desigualdades distributivas de recursos económicos e educativos assim como as desigualdades categoriais entre estados nacionais e entre classes sociais. A fonte de informação empírica foi o European Social Survey 2012. Foi possível calcular decis europeus de rendimentos, construir uma matriz de segmentos classe-país, e analisar as interseções dessa matriz estrutural com as distribuições de rendimentos e escolaridades. Os resultados revelam graus elevados de desigualdade distributiva na Europa. Mostram também as configurações estruturais assumidas na Europa pelas interseções de desigualdades distributivas e categoriais.

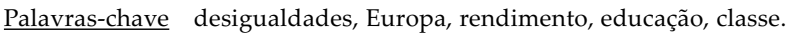

Résumé L'objectif de cet article est de présenter quelques contributions pour la compréhension des inégalités sociales observées aujourd'hui en Europe. L'analyse porte sur les inégalités distributives de ressources économiques et éducatives ainsi que sur les inégalités catégorielles entre États nationaux et entre classes sociales. La source d'information empirique a été l'Enquête sociale européenne (ESS) 2012. Il a été possible de calculer les déciles européens de revenus, de construire une matrice de segments classe-pays et d'analyser les intersections de cette matrice structurelle avec les distributions de revenus et de scolarités. Les résultats révèlent des niveaux élevés d'inégalité distributive en Europe. Ils montrent aussi les configurations structurelles que prennent en Europe les intersections d'inégalités distributives et catégorielles.

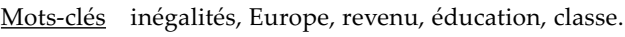


Resumen El objetivo de este artículo es presentar algunas contribuciones para la comprensión de las desigualdades sociales en la Europa actual. Se analizan las desigualdades distributivas de recursos económicos y educativos, así como las desigualdades de categorías entre estados nacionales y entre clases sociales. La fuente de información empírica fue el European Social Survey (ESS) 2012. Fue posible calcular deciles europeos de rendimientos, construir una matriz de segmentos clase-país, y analizar las intersecciones de esa matriz estructural con las distribuciones de rendimientos y escolaridades. Los resultados revelan grados elevados de desigualdad distributiva en Europa. También muestran las configuraciones estructurales asumidas en Europa por las intersecciones de desigualdades distributivas y entre categorías.

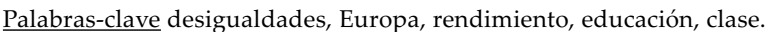

\section{Introduction}

To what extent does Europe currently represent a social space of high inequality? This question emerges from a global context in which socioeconomic inequalities have regained great visibility. In this context, the transversality and structural characteristics of these inequalities, as well as their interlinkage with a variety of other facets of social inequality, have come to the intense analytical attention of sociologists, economists, and other social scientists (Wilkinson and Pickett, 2009; Therborn, 2013; Piketty, 2014; Stiglitz, 2015).

It has often been noted that many European countries exhibit relatively low levels of income inequality compared with other regions of the world. The income inequalities of a large number of European countries are significantly lower than that of the USA, the countries of Latin America, the large emerging Asian nations such as China and India, and the majority of the countries in Africa or the Middle East (OECD, 2011; Bourguignon, 2015). Nordic countries have a particularly low level of income inequality. Additionally, Central European countries such as France, Germany, Belgium, and the Netherlands, among others, also maintain relatively low levels of income inequality compared with those of the majority of the world, even though they experienced a moderate increase in inequalities before and after the Great Recession (Atkinson, 2015; OECD, 2015).

Nonetheless, these European countries represent a different reality than that of Europe as a whole. Despite the ongoing relevance of nation states, the current European transnational space, with its unique institutional configuration, constitutes in itself a framework of social integration, notwithstanding its contradictions and its variable geometry (Beck, 2013; Habermas, 2015). This European social integration is found in a plurality of formal and informal domains, involving institutional frameworks, economic exchanges, social networks, mobility flows, cultural patterns, and hierarchies of power (Favell and Guiraudon, 2011). How, then, are inequalities configured in this transnational social space?

Of the multiple aspects that could be examined in this sphere, in this article, we address two specific questions: (a) what is the range of European inequalities, considering basic distributional dimensions such as economic resources (income) and educational resources (schooling)?; and (b) what is the structure of European 
inequalities, taking into account the intersections of the above mentioned distributional inequalities with categorical inequalities relating to social classes and countries, which are both highly relevant to the socioeconomic constitution of the present-day European transnational space?

We used data from the European Social Survey (ESS, 2012) as empirical support for answering these questions.

\section{Distributional and categorical inequalities in a transnational context}

We adopt a multidimensional concept of inequality in our analysis, following some of the most significant theoretical contributions in the field, such as those of Bourdieu (1979), Tilly (1998), Massey (2007) and Therborn (2013). In contemporary societies, multiple types of relevant inequalities exist; however, they do not share the same levels of importance and their relative contributions are changeable. In addition, diverse types of inequalities can often intersect. Sometimes, these inequalities reinforce each other; at other times, they contradict each other or offset their effects to some extent. Nevertheless, the predominant tendency is the systematic accumulation of multiple dimensions of inequality (Bihr and Pfefferkorn, 2008; Stiglitz, 2012).

The analysis presented in this article specifically focuses on intersections of distributional and categorical inequalities (Costa, 2012a; Costa et al., 2015). Regarding distributional inequalities, we highlight here the unequal distribution of economic (Piketty, 2014) and educational (Breen and Jonsson, 2005) resources. In effect, in the context of a market economy and a "knowledge society", both economic and educational resources are determinant factors of people's living conditions and societal development. Regarding categorical inequalities, we focus on social classes and countries, which are both powerfully structuring social categories in spaces of transnational integration in the context of globalized capitalism, such as the social space of present-day Europe (Favell and Guiraudon, 2009).

Additional relevant inequalities could be studied, including inequalities of gender, age, race, ethnicity, cultural identity, and social capital, or the inequalities in the labour market and welfare state institutions. These and other inequalities are, in fact, very significant. Nevertheless, the distributional inequalities of economic and educational resources as well as the categorical inequalities between social classes and countries are vital for capturing the social structure of European inequality.

In the analysis that follows, we approach the European space as a transnational social context. In general, the conceptions whereby explicit or implicit perspectives of "methodological nationalism" prevailed are no longer applicable to contemporary social reality (Beck, 2006). Now, more than ever, social relations and dynamics, particularly those involving inequalities, are not confined within national borders (Wagner, 2007; Frazer, 2008; Whelan and Maître, 2009; Costa, 2012b; Mau and Mewes, 2012). Accordingly, the present study is grounded in the conception that we 
cannot identify and understand the social inequalities in contemporary Europe unless we expressly analyse them as transnational inequalities (Costa, Machado and Almeida, 2009; Favell and Guiraudon, 2011).

Nevertheless, the avoidance of methodological nationalism (Mau, 2010; Delhey et al., 2014) does not imply abstract globalism. Despite increasing transnational interconnections and interdependencies (a number of them, incidentally, being strongly inegalitarian), social relations and processes remain largely "embedded" (Polanyi, 2001 [1944]) in structures, cultures, and institutions that act in specific and diverse ways within nation states. Rather than analytically neglecting either the European transnational space or the nation states, it seemed pertinent to us to use a theoretical-methodological approach that includes both of these levels of social integration (Elias, 1974) and the relationships between them. Using a conceptual terminology inspired by Norbert Elias (1978), we seek to analyse the European space of inequalities as a multi-level configuration.

\section{Methodology}

The ESS 2012 was the empirical source used in this study. In our analysis, we considered 24 countries covered by the ESS 2012, including the majority of the countries of the European Union and three associated countries in the European Economic Area.

The data that we used refer to individuals between 25 and 64 years of age who were characterized according to income and education (distributional inequalities) and country and social class (categorical inequalities) using a set of harmonized indicators. This age group covers individuals who may have completed high levels of education and joined the workforce, which explains why this age group is frequently used in international comparative studies.

The income variable that was operationalized in this study encompasses all of the components of the monetary income of the household, including income generated from employment or self-employment, property income (interest, dividends, and rent), and transfers. To construct national and European income indicators, we performed a series of standardization and harmonization operations involving currency conversion for the countries that do not use the Euro, the calculation of annual reported income over 12 months, and the calculation of net income for countries with only gross income data available. The year of reference was 2012 for both the currency conversions and for the calculations of annual income.

The ESS income variable is expressed as brackets, therefore it was necessary to calculate the averages of each of the brackets for each country. For the lowest income bracket, a value corresponding to two-thirds of the upper limit of the bracket was adopted. For the top brackets, a value equivalent to one and one-half times the lower limit of this bracket was calculated. In both cases, the criteria referenced in the specialized literature (Layard, Mayraz and Nickell, 2008) were adopted. Any possible biases are likely to be towards an underestimation of inequalities. 
After the average household income was defined for each country, we created a new variable for the net income per individual equivalent for each country. The square root equivalence scale (OECD, 2008) was used for this calculation. Based on the individual incomes, we calculated the income deciles of each country, the share of the deciles and the average income of the deciles. In this approach, we used the ESS post-stratification weights (ESS pspwght), which correct for age group, gender, education, and region (ESS, 2014a).

In the next step, we constructed a transnational aggregated distribution of European deciles using similar procedures as described above. However, we used the total number of individuals included in the sample of the set of countries for calculating the income of each European decile. For this operation, we introduced the ESS newweight, which combines the ESS pspwght with an adjustment for the size of the countries in the context of the sample (ESS pweight) (ESS, 2014b).

For the analyses conducted in this study, the income variable refers to the annual income per adult equivalent after taxes and mandatory contributions on income. This variable was calculated for each country in the analysed European space on an aggregate basis, which made it possible to calculate the European income deciles directly.

The calculation of the European income deciles has the same analytical objectives as the pioneering work by Dauderstädt and Keltek (2011, 2015), i.e., to analyse the inequalities in income distribution in the European population (and not merely between countries). However, from a methodological perspective, the microdata from ESS 2012 allowed for the direct calculation of European income deciles as opposed to the indirect calculation performed with Eurostat source (EU-SILC) by Dauderstädt and Keltek.

Similar to Dauderstädt and Keltek, we calculated incomes in both Purchasing Power Standards (PPS) and Euros. PPS is commonly used in comparative international analyses to adapt the diverse purchasing power of money to each country's economic conditions (see Cingano, 2014, with OECD data and concerned to USA reality). Nonetheless, more and more authors have noted problems with this approach (Anand and Segal, 2008; Deaton, 2010), particularly in Europe (Dauderstädt and Keltek, 2011;2015). In effect, a growing portion of the cost-of-living and economic capacities of Europeans does not have a strictly national character, as evidenced through the following observations: the increasing integration of the European space, the intensification of imports and exports, the international mobility of people in the European space, the online transactions, and the transnationalization of consumption and lifestyles (Mau, 2010; Favell and Guiraudon, 2011; Mau and Mewes, 2012). The level of transnational integration that has already been achieved in the daily lives of Europeans may limit the practicality of using PPS in comparative analyses of European income distributions. Therefore, a more realistic approach would be scaled at some point between the PPS and Euro data. Thus, similar to Dauderstädt and Keltek, we analysed income inequalities using both PPS and Euros.

In the results presented and analysed in the next section, we follow convention and present the values in PPS. However, we are aware that the PPS values likely underestimate the levels of European income inequality. We also present 
certain results in Euros, which tend to overestimate the levels of income inequality in Europe. Thus, it is reasonable to assume that actual European income inequalities are positioned between the two.

Two indicators of schooling that are customarily used in inequality studies are International Standard Classification of Education (ISCED) educational levels and "years of schooling completed". In our approach, we opted to use "years of schooling completed" because it potentially enables the use of a quantitative variable. In addition, the "years of schooling completed" indicator guarantees greater standardization because it is relatively less dependent on the specific educational systems of each country.

Because the ESS databases are organized by country, the nationality variable was operationalized directly. Anyone who was 25 to 64 years old and had valid responses to ESS 2012 from the selected countries was included in the analysis.

The operationalization of the social class variable was performed using the ACM typology (table 1). This typology of class locations, which was proposed by the Portuguese sociologists João Ferreira de Almeida, António Firmino da Costa and Fernando Luís Machado, was used in several European analyses (Costa et al., 2002; Costa, Machado and Almeida, 2009; Carmo and Nunes, 2013; Nunes, 2013). The operationalization of this typology uses occupation (ISCO 08) and employment status as primary variables, combining them in a matrix of class locations.

The ACM typology incorporates the analytical dimensions and classification criteria of several noteworthy contemporary sociologists, such as Bourdieu (1979), Goldthorpe, Llewellyn and Payne (1980) and Wright (1997), for class analysis. It is well known that the theoretical connections and operationalization proposals of these authors differ greatly in many ways. However, they also converge in several aspects, particularly in the relational and structural features that are attributed to social classes. As far as analytical dimensions are concerned, this convergence only occurs up to a point. All of the authors emphasize socio-occupational relations, although Goldthorpe and Wright formalize employment status or location in production relations to a greater extent than the others. Bourdieu's theoretical framework is highly multi-dimensional, particularly in the integration of culture, education, and lifestyles in his analysis of classes. Some of these dimensions, specifically qualifications, are explicitly included in Wright's analytical framework and are implicit in Goldthorpe's classificatory scheme.

Similar consideration can be given to more recent typologies of classes whether they are the classifications of a micro-occupational character developed by Grusky and Sørensen (1998), the socio-economic categories proposed by Rose and Harrison (2007), which is essentially a new version of Goldthorpe's scheme, or the class typology developed by Savage et al. (2013), which was strongly inspired by Bourdieu but updated to reflect new social circumstances.

The ACM typology contains a set of conceptual and operational properties that makes it particularly useful for our analysis. In short, (a) it allows for the operationalization of a set of basic dimensions of contemporary social inequalities, such as employment status, types of occupations, qualification levels, and organizational hierarchies, (b) it can convert other class typologies, such as those of the 


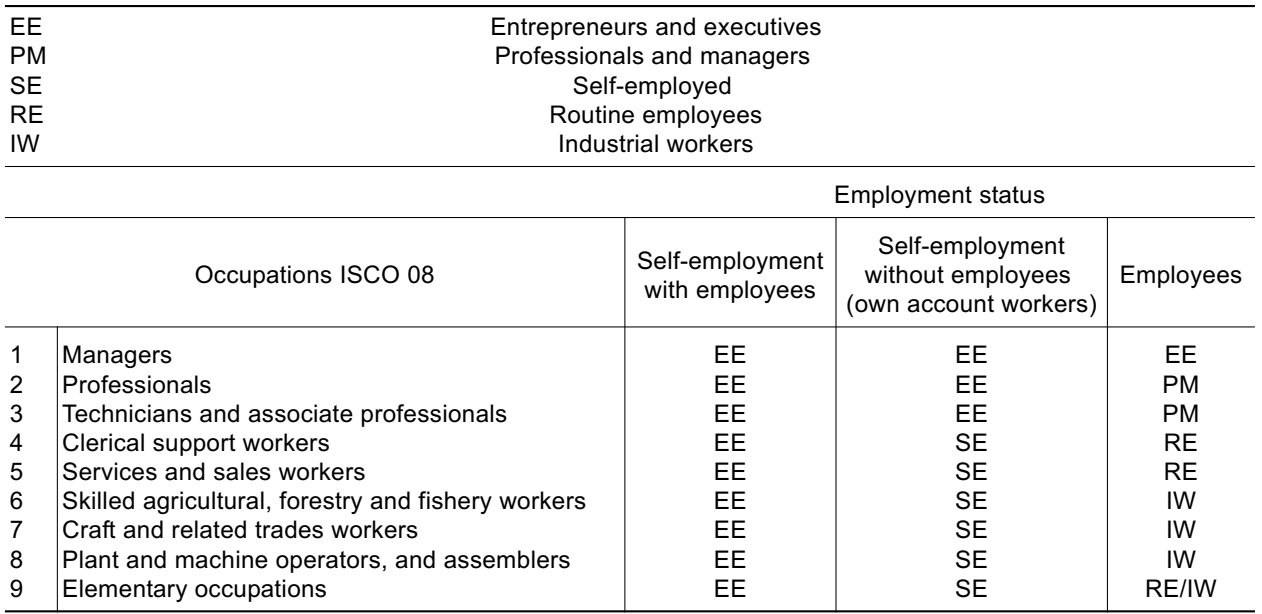

Note: The employees of the 9.1, 9.4, 9.5 and 9.6 occupational groups are classified as RE; the employees of the 9.2 and 9.3 occupational groups are classified as IW.

authors referenced above, to its schema, thus facilitating analytical comparison and cognitive accumulation, (c) it enables the use of both institutional statistical data and research surveys as empirical data sources, $(\mathrm{d})$ it is a very compact classification, which has operational advantages for large-scale comparative analyses, and (e) it allows for more fine-graded versions of the typology depending on the problems and the contexts under analysis, particularly for local or specific study objects (Costa, 1999; Antunes, 2011).

\section{Analysis and discussion of results}

In this section, we present and discuss the results of our analysis using a selection of inequality indicators. In the first analytical step, we sought to identify the range of the income inequalities in the present European social space, considered as a whole. Then, on a deeper analytical level, we sought to identify the structure of European inequalities based on the intersection of a set of distributional inequities and categorical inequalities. The distributional inequalities that we analysed were income and educational inequalities, which refer to the distribution of basic resources in the contemporary context of the market economy and "knowledge society". The categorical inequalities that we considered were countries and social classes, which decisively structure the European area as a space of transnational integration in the context of capitalist globalization.

Table 2 provides a first look at the distributional inequalities in Europe, referring to the yearly average income of European populations per country in 


\begin{tabular}{lcc}
\hline Country & PPS & Euros \\
\hline Bulgaria & 5,506 & 2,588 \\
Hungary & 6,988 & 4,682 \\
Lithuania & 7,250 & 5,220 \\
Poland & 8,743 & 5,858 \\
Portugal & 9,513 & 7,230 \\
Slovakia & 10,073 & 7,809 \\
Estonia & 10,275 & 8,165 \\
Slovenia & 11,172 & 8,462 \\
Czech Republic & 11,499 & 9,049 \\
Spain & 14,778 & 14,554 \\
Cyprus & 15,161 & 14,908 \\
Italy & 15,513 & 15,873 \\
Iceland & 15,873 & 17,840 \\
Ireland & 16,383 & 19,064 \\
France & 17,930 & 20,692 \\
Belgium & 18,157 & 21,789 \\
Netherlands & 18,983 & 22,772 \\
Germany & 19,079 & 23,467 \\
United Kingdom & 24,274 & 25,859 \\
Finland & 24,864 & 27,915 \\
Sweden & 26,004 & 33,396 \\
Denmark & 26,505 & 37,477 \\
Norway & 29,744 & 50,448 \\
Switzerland & 35,132 & 55,509 \\
Europe & 17,917 & 19,941 \\
\hline & & \\
\hline
\end{tabular}

Source: ESS 2012

PPS and Euros. This corresponds to conventional analyses of economic inequality in Europe, which are performed by comparing the averages of national incomes. As observed in table 2, the ratio of the average of the country with the highest incomes (Switzerland) to the average of the country with the lowest incomes (Bulgaria) is 6:1 in PPS. If we use Euros, a nearly 21-fold inequality is apparent. As stated previously, neither of these two monetary units is completely satisfactory for comparative analyses in social contexts with a considerable degree of transnational integration; therefore, actual income inequalities are likely between 6- and 21-fold.

A more detailed reading of table 2 reveals powerful income disparities in these countries. The Eastern European countries, as well as Portugal, have relatively lower incomes. In contrast, the national populations located in Central and Northern Europe have relatively high average annual incomes.

This approach, however, does not allow for the integrated analysis of income inequalities that occur in the European population as a whole. European income inequalities are the result of a combination of inequalities both between and within countries (Korzeniewicz and Moran, 2009; Milanovic, 2012; Lakner and Milanovic, 2013; Bourguignon, 2015). For these European income inequalities to be captured directly, it is necessary to position each individual in the income distribution of the aggregate European population. 
Using the ESS 2012 microdata, an aggregate sample of the European population was generated. As explained in the methodology section, this sample includes individuals in 24 countries who were integrated into an aggregate population sample of Europe. This aggregation made it possible to calculate European income deciles, that is, the income deciles of the European population considered as a whole. Table 3 shows the results of this analytical operation.

The range of European income inequality using these European deciles is extremely pronounced. The results show a ratio of 12:1 of the $10 \%$ of Europeans with the highest incomes to the $10 \%$ of Europeans with the lowest incomes. In other words, the $10 \%$ of Europeans with the highest incomes have an average income level that is 12 -fold higher than that of the $10 \%$ of Europeans with the lowest incomes. This is a substantial level of inequality. If the calculations are made in Euros, the resulting ratio is an impressive 19:1.

An important contribution of the present analysis consists, then, in the measurement of income inequality in the aggregate European space in terms of the distribution of the entire European population (24 countries in total) in European income deciles. Our analysis reveals that the income inequality in the European space is between 12- and 19-fold in PPS and Euros, respectively.

This result, while interesting on its own, also enables us to conduct an analysis of the intersections of distributional and categorical inequalities in Europe. How are the distributional income inequalities in the European space related to the categorical inequalities between countries and social classes which structure this transnational space?

The relationships of the income distribution in Europe to these categorical variables are of interest, and we analysed them preliminarily. In fact, we initiated the analysis of our results by presenting a table that compares the countries in Europe based on their average incomes (table 2). As previously noted, this relationship is quite evident. In short, the countries of Northern and Central Europe, which have relatively high incomes, lie in opposition to the countries of Southern and Eastern Europe, which have relatively low incomes. The relationship between incomes and social classes is similar; entrepreneurs and executives (EE) and professionals and managers (PM) have, on average, higher income levels than self-employed (SE) individuals, routine employees (RE), and industrial workers (IW), which comes as no surprise.

This analysis, however, is relatively trivial and does not clarify the structural configurations of inequality in the European space. Thus, rather than using a variable-oriented analysis, it seemed more promising to explore a case-oriented analytical approach that allows for the identification of the structural configurations of inequality in the European social space. Therefore, we performed an integrated analysis of multiple cases characterized by combinations of the structural properties of the European space. To accomplish this, we used two types of social categories, namely, countries and classes. The cases considered in our analysis are therefore the various class-country segments in the European social space, as shown in tables 5 and 6.

To perform the analysis, it was necessary to characterize the matrix structure of the relationships that are established between classes and countries in the European space. 


\begin{tabular}{ccc}
\hline Deciles & Income (brackets) & Income (average) \\
\hline 1 & $<=5,581$ & 4,004 \\
2 & $5,582-7,807$ & 6,650 \\
3 & $7,808-9,601$ & 8,489 \\
4 & $9,602-12,149$ & 10,750 \\
5 & $12,150-14,456$ & 13,213 \\
6 & $14,457-17,181$ & 15,637 \\
7 & $17,182-20,650$ & 18,700 \\
8 & $20,651-24,737$ & 22,548 \\
9 & $24,738-35,062$ & 29,120 \\
10 & $>=35,063$ & 48,875 \\
\hline
\end{tabular}

Source: ESS 2012.

Accordingly, table 4 displays the distributions of the class locations by country and in Europe as a whole. It is possible to identify a European social composition with almost $50 \%$ of the base wage earners. Among these, the routine employees (RE), who perform low-skilled activities of an administrative, commercial, or service nature, are currently more numerous in Europe (nearly 28\%) than industrial workers (IW). Nevertheless, IW encompass nearly $22 \%$ of Europeans in the labour force.

Almost a third of the active European population corresponds to professionals and managers (PM), i.e., employees with higher or intermediate qualifications (approximately $31 \%$ ). The PM constitute a large fraction of today's "salaried middle classes" in Europe, and they play a significant role in the contemporary dynamics of the so-called "knowledge society".

The entrepreneurs and executives (EE), who hold positions at the apex of the asymmetrical relationships of property, power, and status, represent $13.5 \%$ of the European population. It is worth noting, however, that between one half to two-thirds of the EE are actually small business entrepreneurs, whose structural situation is very similar to that of the self-employed (SE). The SE (nearly $6 \%$ of Europeans) represent a segment of today's middle classes that is defined by small business ownership and autonomous work. In this sense, they can be considered together with the aforementioned small entrepreneurs; however, the SE are more similar to base wage earners in qualifications and income levels.

The transnational structure of class locations in the European space has specific embodiments in the context of different countries - an issue with very significant implications (Costa et al., 2002; Costa, Machado and Almeida, 2009) that will not be addressed in this article. In contrast, we examine here how two basic resources in modern societies (income and education) are distributed in a transnational structural matrix that interlinks the classes and countries in the European social space.

In operative terms, as previously mentioned, this matrix enables us to discern a set of class-country segments in the European social space. The structural 
Table 4

Social classes by European country, age group 25-64, 2012 (row \%)

\begin{tabular}{|c|c|c|c|c|c|}
\hline \multirow{2}{*}{ Country } & \multicolumn{5}{|c|}{ Social class } \\
\hline & EE & PM & SE & RE & IW \\
\hline Germany & 12.7 & 34.1 & 3.7 & 29.2 & 20.3 \\
\hline Belgium & 19.4 & 33.7 & 3.0 & 26.3 & 17.6 \\
\hline Bulgaria & 10.2 & 21.6 & 5.2 & 31.7 & 31.3 \\
\hline Cyprus & 14.9 & 27.2 & 6.4 & 34.5 & 16.9 \\
\hline Denmark & 12.3 & 31.7 & 2.5 & 37.2 & 16.2 \\
\hline Slovakia & 9.6 & 21.6 & 3.9 & 30.6 & 34.2 \\
\hline Slovenia & 13.9 & 31.7 & 3.9 & 21.4 & 29.1 \\
\hline Spain & 13.0 & 31.7 & 6.7 & 27.9 & 20.8 \\
\hline Estonia & 17.1 & 30.7 & 2.8 & 21.1 & 28.3 \\
\hline Finland & 11.2 & 38.9 & 5.1 & 25.7 & 19.0 \\
\hline France & 9.6 & 35.3 & 2.6 & 30.8 & 21.7 \\
\hline Netherlands & 17.3 & 38.4 & 4.3 & 29.4 & 10.7 \\
\hline Hungary & 7.1 & 25.6 & 4.9 & 28.5 & 34.0 \\
\hline Ireland & 17.1 & 24.5 & 6.9 & 34.2 & 17.3 \\
\hline Island & 24.2 & 36.3 & 5.9 & 20.6 & 13.0 \\
\hline Italy & 13.7 & 27.9 & 8.6 & 23.4 & 26.4 \\
\hline Lithuania & 7.8 & 22.2 & 3.4 & 28.8 & 37.8 \\
\hline Norway & 11.2 & 43.2 & 3.2 & 27.3 & 15.2 \\
\hline Poland & 17.3 & 26.1 & 10.6 & 19.7 & 26.2 \\
\hline Portugal & 7.2 & 17.8 & 7.7 & 33.2 & 34.1 \\
\hline United Kingdom & 16.4 & 28.5 & 7.4 & 32.2 & 15.5 \\
\hline Czech Republic & 10.5 & 29.4 & 4.9 & 28.8 & 26.4 \\
\hline Sweden & 15.5 & 39.4 & 3.5 & 26.2 & 15.4 \\
\hline Switzerland & 19.9 & 38.5 & 4.4 & 24.0 & 13.2 \\
\hline Europe & 13.5 & 31.1 & 5.7 & 28.1 & 21.6 \\
\hline
\end{tabular}

Source: ESS 2012.

configuration of European inequalities is quite visible when we analyse the positions of these class-country segments in the previously calculated European income deciles (table 5). It is then possible to relate the income inequalities in the European population as a whole to the matrix structure that combines the categorical inequalities between classes and countries in the transnational European space. This is the central analysis of our study.

Table 5 reveals the inegalitarian manner in which the various class-country segments are positioned in the European income deciles. In certain countries, all of the classes are positioned in the lower European income deciles despite the inequalities that exist between them. In other countries, the opposite phenomenon occurs, with all of the classes being positioned in the higher European income deciles despite the income inequalities between these classes. In the majority of the cases, the class-country segments are positioned in the intermediate zones of the European income distribution. Within each country, the classes are distributed in brackets consisting of four to five European income deciles. When the incomes are calculated in Euros, the relative positions in the European space confirm significant inequalities. Moreover, the structural configuration of the inequalities in the European space using Euros generally coincides with that using PPS, with only minor differences. In both PPS and Euros, the intersection between income distributions and 


\begin{tabular}{|c|c|c|c|c|c|c|}
\hline \multirow{2}{*}{ Country } & \multicolumn{5}{|c|}{ Social class } & \multirow{2}{*}{ Total } \\
\hline & EE & PM & SE & RE & IW & \\
\hline Bulgaria & 2 & 2 & 1 & 1 & 1 & 1 \\
\hline Hungary & 2 & 3 & 2 & 2 & 2 & 2 \\
\hline Lithuania & 4 & 3 & 3 & 2 & 2 & 2 \\
\hline Poland & 5 & 4 & 2 & 2 & 2 & 3 \\
\hline Portugal & 4 & 6 & 3 & 3 & 3 & 3 \\
\hline Slovakia & 5 & 5 & 3 & 3 & 3 & 4 \\
\hline Estonia & 6 & 5 & 4 & 3 & 3 & 4 \\
\hline Slovenia & 6 & 5 & 5 & 3 & 4 & 4 \\
\hline Czech Republic & 6 & 5 & 3 & 3 & 4 & 4 \\
\hline Spain & 7 & 7 & 5 & 5 & 4 & 6 \\
\hline Cyprus & 8 & 7 & 4 & 4 & 4 & 6 \\
\hline Italy & 7 & 6 & 5 & 6 & 5 & 6 \\
\hline Iceland & 7 & 8 & 4 & 6 & 4 & 6 \\
\hline Ireland & 7 & 8 & 6 & 5 & 5 & 6 \\
\hline France & 8 & 7 & 6 & 6 & 5 & 7 \\
\hline Belgium & 8 & 7 & 5 & 6 & 5 & 7 \\
\hline Netherlands & 9 & 8 & 6 & 6 & 6 & 7 \\
\hline Germany & 8 & 8 & 6 & 6 & 5 & 7 \\
\hline United Kingdom & 9 & 9 & 7 & 8 & 7 & 8 \\
\hline Finland & 9 & 9 & 7 & 7 & 7 & 9 \\
\hline Sweden & 9 & 9 & 8 & 8 & 8 & 9 \\
\hline Denmark & 9 & 9 & 7 & 8 & 8 & 9 \\
\hline Norway & 10 & 9 & 8 & 9 & 9 & 9 \\
\hline Switzerland & 10 & 10 & 8 & 9 & 9 & 10 \\
\hline Europe & 8 & 8 & 5 & 6 & 5 & 7 \\
\hline
\end{tabular}

Source: ESS 2012.

the class-country categorical structures in the European space forms a very inegalitarian configuration.

One contribution of the present study is that it provides an analysis of the intersection between the distributions of resources of great social importance (incomes) and a structural matrix of institutions central to modernity - the nation state (in the context of globalization and, specifically, transnational integration in the European space) and the capitalist social division of labour (in the phase of "advanced modernity" or the "knowledge society").

In this societal context, in addition to the asymmetric relationships inherent in economic resources, an asymmetric distribution of educational resources is also a basic component of the system of inequalities. A characterization of the intersection between the distributional inequalities of educational resources and the structural matrix of categorical inequalities (classes $x$ countries) is shown in table 6.

The formation of a European space of inequalities is also evident in table 6 . The locations of class-country segments in the European distribution of educational resources (operationalized by years of schooling) reveals an inegalitarian structure that is partially similar to but also partially different from the structure of economic resource inequalities (Meschi and Scervini, 2012). With respect to 
Table 6 Educational inequalities in Europe by social class and country, age group 25-64, 2012 (average years of schooling completed)

\begin{tabular}{|c|c|c|c|c|c|c|}
\hline \multirow{2}{*}{ Country } & \multicolumn{5}{|c|}{ Social class } & \multirow{2}{*}{ Total } \\
\hline & EE & PM & SE & RE & IW & \\
\hline Portugal & 11 & 15 & 7 & 9 & 7 & 9 \\
\hline Bulgaria & 14 & 15 & 11 & 11 & 11 & 12 \\
\hline Italy & 13 & 15 & 10 & 12 & 9 & 12 \\
\hline Switzerland & 14 & 14 & 10 & 11 & 10 & 12 \\
\hline Slovenia & 15 & 15 & 11 & 12 & 10 & 13 \\
\hline Hungary & 15 & 15 & 13 & 12 & 11 & 13 \\
\hline France & 15 & 15 & 12 & 12 & 11 & 13 \\
\hline Poland & 15 & 15 & 12 & 12 & 11 & 13 \\
\hline Cyprus & 15 & 16 & 11 & 12 & 11 & 13 \\
\hline Slovakia & 15 & 15 & 13 & 13 & 12 & 13 \\
\hline Czech Republic & 15 & 15 & 13 & 13 & 12 & 13 \\
\hline Lithuania & 15 & 15 & 13 & 13 & 12 & 13 \\
\hline Belgium & 15 & 15 & 12 & 12 & 11 & 14 \\
\hline Denmark & 15 & 15 & 13 & 13 & 12 & 14 \\
\hline Norway & 15 & 16 & 11 & 12 & 12 & 14 \\
\hline Estonia & 15 & 16 & 13 & 13 & 12 & 14 \\
\hline United Kingdom & 15 & 16 & 12 & 13 & 12 & 14 \\
\hline Sweden & 14 & 16 & 13 & 12 & 12 & 14 \\
\hline Spain & 17 & 18 & 12 & 12 & 11 & 14 \\
\hline Germany & 17 & 16 & 14 & 13 & 12 & 14 \\
\hline Finland & 15 & 17 & 12 & 13 & 12 & 15 \\
\hline Ireland & 16 & 17 & 14 & 14 & 13 & 15 \\
\hline Netherlands & 16 & 16 & 13 & 13 & 12 & 15 \\
\hline Iceland & 17 & 17 & 13 & 14 & 13 & 16 \\
\hline Europe & 15 & 16 & 12 & 12 & 11 & 13 \\
\hline
\end{tabular}

Source: ESS 2012.

educational inequalities, there is a clear break between the base wage earners (RE, IW) and the low-skilled self-employed (SE) on one hand and the dominant classes (EE) and salaried middle classes (PM) on the other. This European educational divide separates, on average, the social classes associated with 15-16 years of schooling from those with 11-12 years of schooling.

Although it is not possible to present here a detailed country-by-country analysis, we cannot fail to notice that in Portugal certain classes are particularly devoid of educational resources considering the European context, particularly the base wage earners and self-employed (RE, IW, and SE). The entrepreneurs and executives (EE) class is also positioned negatively in this context. The salaried middle classes (PM) in Portugal approach the educational resource levels of their European counterparts; however, the salaried middle classes in Portugal account for only around half of that of the European average (table 4). The intersections of educational inequalities with European social structures are manifested in many aspects and in various configurations (Martins, 2012). 


\section{Conclusions}

In this article, we presented the results of a research project on the constitution of a European space of inequalities. This transnational space is currently characterized by very sharp inequalities in economic resources (income), whether we examine these inequalities with European deciles or analyse them more structurally by class-country segments.

In this transnational European space, there is a marked "horizontal" economic divide between country groups, particularly between those whose populations are transversally located in the topmost European income deciles and those whose respective populations are transversally positioned in the lower European income deciles.

The European space is also characterized by relevant, albeit less marked, educational inequalities. In this regard, we find an overall "vertical" divide between the propertied, managerial, and professional classes, on one hand, and the base wage earners and independent workers, on the other. In addition, certain countries exhibit an educational profile that is substantially lower than the European average.

These analyses thus enable us to suggest a number of contributions to various topics at the centre of the current debates on inequalities. One such debate involves the importance of analysing inequalities in Europe as a whole. The fact is that so far most of the analyses of inequality in Europe, and particularly those regarding income inequality, have focused on the inequalities within each individual European country. It is well known that these national inequalities are relatively small compared to those in other countries and regions around the world. Even the Eurostat data on this subject are actually the averages of the inequalities recorded in each European country.

The trouble is that this procedure does not reveal the full extent of the inequalities in the European area. It is thus important to really look at the continent as a whole when determining inequality in Europe. Surprisingly, few works have considered the pertinence of and need for an examination of this question at a truly European level of analysis. There have been some important exceptions, like Dauderstädt and Keltek (2011; 2015) or Fredriksen (2012), who do present arguments and analyses that go in this direction. We hope that our own contribution can also help to achieve recognition of how important this transnational level of analysis is when it comes to measuring and understanding European inequalities.

When we look at income inequalities at a transnational European level, their extent seems quite substantial, as we have seen. This is the case even when we situate the European values within the global context. For example, Palma (2011) and the OECD (2015) show that the ratios of the top to the bottom income deciles in the USA are not much greater than those we have calculated for the European area.

Another debate on current inequalities asks whether the trend towards the rise in economic inequalities is taking place primarily within countries, or between countries (Milanovic, 2012; Anand and Segal, 2015). The fact that this trend is visible around the world, namely in the US and the so-called emerging countries, does 
not in itself mean that it can be directly transposed to the European case. However, as we have demonstrated in the present article, economic inequality in today's Europe presents some important divergences between countries. At the same time, internal inequalities have been increasing in many European countries (Braconier and Ruiz-Valenzuela, 2014; OECD, 2011 and 2015). Taken together, these two processes are responsible for the high level of economic inequality that we found in Europe at the present time.

A third debate to which this article can hopefully contribute involves the current relevance of class inequalities. Here, our approach is not just another take on the dispute between classic paradigms and their recent applications (Wright, 2015). We have instead drawn on contributions made not only by Goldthorpe, Llewellyn and Payne (1980) and Wright (1997), but also by Bourdieu (1979), Tilly (1998), Massey (2007), Therborn (2013) and Savage et al. (2015), in order to analyse class inequalities within the broader concept of categorical inequalities. This conceptual approach has allowed us to analyse transnational structures of categorical inequalities - in this case, intersection structures between classes and countries in Europe. It has also enabled us to analyse the intersections between these categorical inequalities and distributional inequalities of economic and educational resources in Europe.

The results are significant. In summary, the present European space of inequalities exhibits very unequal distributions of economic and educational resources, with particularly strong income inequalities. This European space of inequalities rests upon two decisive structural elements: nation states and social classes. Therefore, it involves two central dimensions of advanced modernity, namely, state organization (in the process of transnational integration), and the capitalist social division of labour (in the "knowledge society" stage). Additionally, this European space of inequality is shaped as a two-level configuration: national and transnational. In this configuration, European inequalities are particularly significant. These marked European inequalities may be unexpected given the manifest objectives of European institutions and policies over the last half century. However, European inequalities are currently very high and have large implications.

The analyses presented in this article are part of an on-going research project seeking to capture European inequalities from a multidimensional perspective. We have herein tested a set of theoretical concepts, methodological procedures, and interpretive inferences regarding European inequalities. We believe that our results can contribute to the advancement of knowledge and critical debate on the inequalities in contemporary Europe. We are fully aware that these contributions must be re-examined and deepened, particularly by incorporating additional analytical dimensions and by comparing our results with novel sources of empirical information. These future developments may consider the proposals that we present in this study: (a) the relevance of analysing the inequalities in Europe as a whole and (b) the heuristic potential of placing the intersections of distributional inequalities (of economic and educational resources) with categorical inequalities (between nation states and social classes) at the heart of this analysis. 


\section{References}

Anand, Sudhir, and Paul Segal (2008), “What do we know about global income inequality?", Journal of Economic Literature, 46 (1), pp. 57-94.

Anand, Sudhir, and Paul Segal (2015), "The global distribution of income", in Anthony B. Atkinson, and François Bourguignon (Eds.), Handbook of Income Distribution, vol. 2A, Amsterdam, Elsevier, pp. 937-979.

Antunes, Ricardo Jorge (2011), "The social space of health inequalities in Portugal", Social Theory \& Health, 9 (4), pp. 393-409.

Atkinson, Anthony B. (2015), Inequality. What Can Be Done?, Cambridge, MA, Harvard University Press.

Beck, Ulrich (2006), Cosmopolitan Vision, Cambridge, UK, Polity Press.

Beck, Ulrich (2013), German Europe, Cambridge, UK, Polity Press.

Bihr, Alain, and Roland Pfefferkorn (2008), Le Système des Inégalités, Paris, Editions La Découverte.

Bourdieu, Pierre (1979), La Distinction. Critique Sociale du Jugement, Paris, Les Editions de Minuit.

Bourguignon, François (2015), The Globalization of Inequality, Princeton, Princeton University Press.

Braconier, Henrik, and Jenifer Ruiz-Valenzuela (2014), “Gross earning inequalities in OECD countries and major non-member economies: determinants and future scenarios", OECD Economics Department Working Papers, No. 1139.

Breen, Richard, and Jan O. Jonsson (2005), "Inequality of opportunity in comparative perspective: recent research on educational attainment and social mobility", Annual Review of Sociology, 31, pp. 223-243.

Carmo, Renato Miguel do, and Nuno Nunes (2013), “Class and social capital in Europe: a transnational analysis of the European Social Survey", European Societies, 15 (3), pp. 373-387.

Cingano, Federico (2014), "Trends in income inequality and its impact on economic growth", OECD Social, Employment and Migration Working Papers, No. 163, OECD Publishing, available at: http://dx.doi.org/10.1787/5jxrjncwxv6j-en. (last access April 2016).

Costa, António Firmino da (1999), Sociedade de Bairro. Dinâmicas Sociais da Identidade Cultural [Neighbourhood Society: Social Dynamics of Cultural Identity], Oeiras, Celta Editora.

Costa, António Firmino da (2012a), Desigualdades Sociais Contemporâneas [Contemporary Social Inequalities], Lisbon, Editora Mundos Sociais.

Costa, António Firmino da (2012b), “Desigualdades globais" [Global inequalities], Sociologia Problemas e Práticas, 68, pp. 9-32.

Costa, António Firmino da, Rosário Mauritti, Susana da Cruz Martins, Fernando Luís Machado, and João Ferreira de Almeida (2002), "Social classes in Europe", Portuguese Journal of Social Science, 1 (1), pp. 5-39.

Costa, António Firmino da, Fernando Luís Machado, and João Ferreira de Almeida (2009), “Social classes and educational assets: a transnational analysis", in António Firmino Costa, Fernando Luís Machado, and Patrícia Ávila (Eds.), Knowledge and Society (Portugal in the European Context, vol. II), Oeiras, Celta Editora, pp. 5-20. 
Costa, António Firmino da, Rosário Mauritti, Susana da Cruz Martins, Nuno Nunes, and Ana Lúcia Romão (2015), “A constituição de um espaço europeu de desigualdades", Observatório das Desigualdades e-Working Paper, No. 1/2015, pp. 1-21, ISCTE-IUL, CIES-IUL.

Dauderstädt, Michael, and Cem Keltek (2011), "Immeasurable inequality in the European Union", Intereconomics, 1, pp. 44-51.

Dauderstädt, Michael, and Cem Keltek (2015), “Social Europe in the crisis”, Berlin, Friedrich-Ebert-Stiftung.

Deaton, Angus (2010), "Price indexes, inequality, and the measurement of poverty", The American Economic Review, 100 (1), pp. 5-34.

Delhey, Jan, Emanuel Deutschmann, Timo Graf, and Katharina Richter (2014), “Measuring the Europeanization of everyday life", European Societies, 16 (3), pp. 355-377.

Elias, Norbert (1974), "Towards a theory of communities", in Colin Bell, and Howard Newby (Eds.), The Sociology of Community, London, Frank Cass, pp. ix-xli.

Elias, Norbert (1978), What is Sociology? London, Hutchinson.

ESS (2014a), Documentation of ESS Post-Stratification Weights, available at: http://www.europeansocialsurvey.org/docs/methodology/ESS_post_stratification_ weights_documentation.pdf (last access April 2016).

ESS (2014b), Weighting European Social Survey Data, available at: http://www.europeansocialsurvey.org/docs/methodology/ESS_weighting_data_1.p df (last access April 2016).

Favell, Adrian, and Virginie Guiraudon (2009), “The sociology of the European Union: an agenda", European Union Politics, 10 (4), pp. 550-576.

Favell, Adrian, and Virginie Guiraudon (Eds.), (2011), Sociology of the European Union, London, Palgrave Macmillan.

Frazer, Nancy (2008), Scales of Justice, Cambridge, UK, Polity Press.

Fredriksen, Kaja Bonesmo (2012), "Income inequality in the European Union”, OECD Economics Department Working Papers, No. 952.

Goldthorpe, John, Catriona Llewellyn, and Clive Payne (1980), Social Mobility and Class Structure in Modern Britain, Oxford, Oxford University Press.

Grusky, David B., and Jesper B. Sørensen (1998), "Can class analysis be salvaged?", American Journal of Sociology, 103 (5), pp. 1187-1224.

Habermas, Jürgen (2015), The Lure of Technocracy, Cambridge, UK, Polity Press.

Korzeniewicz, Roberto Patricio, and Timothy Patrick Moran (2009), Unveiling Inequality, A World-Historical Perspective, New York, Russel Sage Foundation.

Lakner, Christoph, and Branko Milanovic (2013), “Global Income Distribution: from the fall of the Berlin wall to the great recession", Policy Research Working Paper, No. 6719, The World Bank.

Layard, Richard, Guy Mayraz, and Stephen Nickell (2008), “The marginal utility of income", Journal of Public Economics, 92 (8-9), pp. 1846-1857.

Martins, Susana da Cruz (2012), Escolas e Estudantes da Europa [Schools and Students in Europe], Lisbon, Editora Mundos Sociais.

Massey, Douglas S. (2007), Categorically Unequal, New York, Russell Sage Foundation.

Mau, Steffen (2010), Social Transnationalism. Lifeworlds Beyond the Nation-State, London, Routledge. 
Mau, Steffen, and Jan Mewes (2012), “Horizontal europeanisation in contextual perspective", European Societies, 14 (1), pp. 7-34.

Meschi, Elena, and Francesco Scervini (2012), “Expansion of schooling and educational inequality in Europe: Educational Kuznets curve revisited", AIAS, GINI Discussion Paper, No. 61.

Milanovic, Branko (2012), “Global income inequality by the numbers: in history and know", Policy Research Working Paper, No. 6259, The World Bank.

Nunes, Nuno (2013), Desigualdades Sociais e Práticas de Ação Coletiva na Europa [Social Inequalities and Practices of Collective Action in Europe], Lisbon, Editora Mundos Sociais.

OECD (2008), Growing Unequal? Income Distribution and Poverty in OECD Countries, Paris, OECD Publishing.

OECD (2011), Divided We Stand. Why Inequality Keeps Rising, Paris, OECD Publishing.

OECD (2015), In It Together. Why Less Inequality Benefits All, Paris, OECD Publishing.

Palma, José Gabriel (2011), “Homogeneous middles vs. heterogeneous tails, and the end of the 'Inverted-U': it's all about the share of the rich", Development and Change, 42 (1), pp. 87-153.

Piketty, Thomas (2014), Capital in the Twenty-First Century, Cambridge, MA, The Belknap Press of Harvard University Press.

Polanyi, Karl (2001 [1944]), The Great Transformation, Boston, Beacon Press.

Rose, David, and Eric Harrison (2007), “The European socio-economic classification: a new social class schema for comparative European research", European Societies, 9 (3), pp. 459-490.

Savage, Mike, Fiona Devine, Niall Cunningham, Mark Taylor, Yaojun Li, Johs Hjellbrekke, Brigitte Le Roux, Sam Friedman, and Andrew Miles (2013), “A new model of social class?", Sociology, 47 (2), pp. 219-250.

Savage, Mike, Niall Cunningham, Fiona Devine, Sam Friedman, Daniel Laurison, Lisa McKenzie, Andrew Miles, Helene Snee, and Paul Wakeling (2015), Social Class in the $21^{\text {st }}$ Century, London, Pelican.

Stiglitz, Joseph E. (2012), The Price of Inequality, New York, W. W. Norton.

Stiglitz, Joseph E. (2015), The Great Divide, New York, W. W. Norton.

Therborn, Göran (2013), The Killing Fields of Inequality, Cambridge, UK, Polity Press.

Tilly, Charles (1998), Durable Inequality, Berkeley, CA, University of California Press.

Wagner, Anne-Catherine (2007), Les Classes Sociales dans la Mondialisation, Paris, Editions La Découverte.

Whelan, Christopher T., and Bertrand Maître (2009), “The 'Europeanisation' of reference groups", European Societies, 11 (2), pp. 283-309.

Wilkinson, Richard, and Kate Pickett (2009), The Spirit Level, London, Allen Lane.

Wright, Erik Olin (1997), Class Counts, Cambridge, Cambridge University Press.

Wright, Erik Olin (2015), Understanding Class, London, Verso. 
Rosário Mauritti (corresponding author). Assistant Professor at the Department of Sociology, School of Sociology and Public Policy, ISCTE - Lisbon University Institute; researcher at the Centre for Research and Studies in Sociology (CIES-IUL), Av. das Forças Armadas, 1649-026 Lisboa, Portugal. E-mail: rosario.mauritti@iscte.pt

Susana da Cruz Martins. Postdoctoral researcher at the Centre for Research and Studies in Sociology (CIES-IUL); Assistant Professor at the Department of Public Policy, School of Sociology and Public Policy, ISCTE - Lisbon University Institute. E-mail: susana.martins@iscte.pt

Nuno Nunes. Postdoctoral researcher at the Centre for Research and Studies in Sociology (CIES-IUL), ISCTE - Lisbon University Institute.

E-mail: nuno.nunes@iscte.pt

Ana Lúcia Romão. Assistant Professor at School of Social and Political Sciences (ISCSP-ULisboa); Associate researcher of Centre for Research and Studies in Sociology (CIES-IUL), ISCTE - Lisbon University Institute.

E-mail: anaromao@iscsp.ulisboa.pt

António Firmino da Costa. Full Professor at the Department of Sociology, School of Sociology and Public Policy, ISCTE - Lisbon University Institute; researcher at the Centre for Research and Studies in Sociology (CIES-IUL).

E-mail: antonio.costa@iscte.pt

Receção: 4 de março de 2016 Aprovação: 6 de maio de 2016 